UCRL-ID-125176

\title{
The Effects of Diesel Exhaust on the Microbiota within a Tuffaceous Tunnel System
}

D. L. Haldeman

T. Lagadinos

L. Hersman

A. Meike

P. S. Amy

DECENE

DEC 09 1946

OSTI

Manuscript Date: May 1995

Publication Date: August 1996

This is an informal report intended primarily for internal or limited external distribution. The opinions and conclusions stated are those of the author and may or may not be those of the Laboratory.

Work performed under the auspices of the U.S. Department of Energy by the Lawrence Livermore National Laboratory under Contract W-7405-Eng-48.

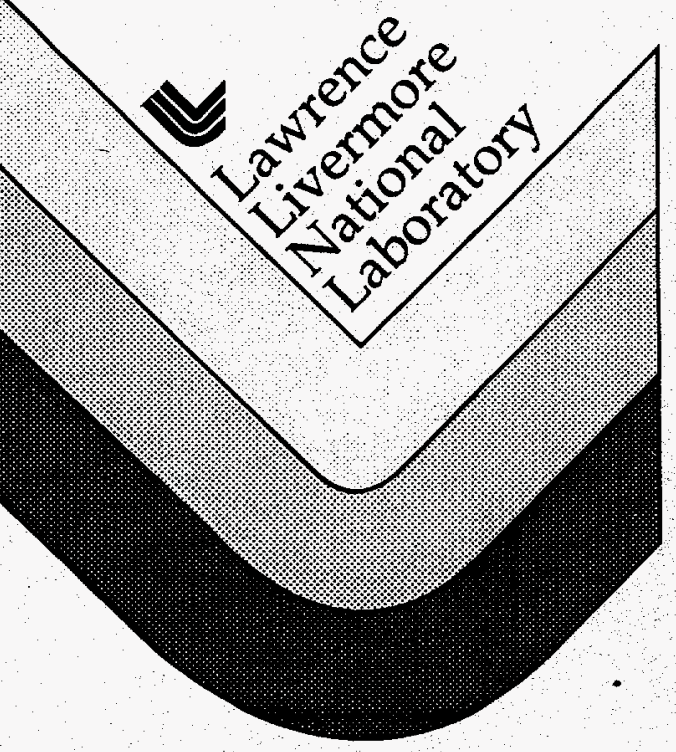




\section{DISCLAIMER}

This document was prepared as an account of work sponsored by an agency of the United States Government. Neither the United States Government nor the University of California nor any of their employees, makes any warranty, express or implied, or assumes any legal liability or responsibility for the accuracy, completeness, or usefulness of any information, apparatus, product, or process disclosed, or represents that its use would not infringe privately owned rights. Reference herein to any specific commercial products, process, or service by trade name, trademark, manufacturer, or otherwise, does not necessarily constitute or imply its endorsement, recommendation, or favoring by the United States Government or the University of California. The views and opinions of authors expressed herein do not necessarily state or reflect those of the United States Government or the University of California, and shall not be used for advertising or product endorsement purposes.

This report has been reproduced directly from the best available copy.

Available to DOE and DOE contractors from the

Office of Scientific and Technical Information

P.O. Box 62, Oak Ridge, TN 37831

Prices available from (615) 576-8401

Available to the public from the

National Technical Information Service

U.S. Department of Commerce

5285 Port Royal Road

Springfield, VA 22161

Prepared by Yucca Mountain Site Characterization Project (YMP) participants as part of the Civilian Radioactive Waste Management Program. The YMP is managed by the Yucca Mountain Site Characterization Project Office of the U.S. Department of Energy, Las Vegas, Nevada. 
The Effects of Diesel Exhaust on the Microbiota within a Tuffaceous Tunnel System

${ }^{1}$ D. L. Haldeman, ${ }^{1}$ T. Lagadinos, ${ }^{2}$ L. Hersman, ${ }^{3}$ A. Meike and ${ }^{~}$ P. S. Amy

${ }^{1}$ Department of Biological Sciences, University of Nevada, Las Vegas, NV, ${ }^{2}$ Los Alamos National Laboratory, Los Alamos, NM, ${ }^{3}$ Lawrence Livermore National Laboratory, Livermore, CA

Correspondence to: Dana Haldeman, Biological Sciences Dept, University of Nevada, Las Vegas, 4505 Maryland Pkwy, Las Vegas, NV 89154-4004. Phone:(702) 895-3288 FAX 702-895-3956 


\section{ABSTRACT}

The abundance and distribution of microbiota that may be impacted by diesel and diesel exhaust were investigated from three depths into the walls and invert (floor) of U12n tunnel at Rainier Mesa, Nevada Test Site, a potential geological analog of Yucca Mountain. Enumerations included total cell counts, and numbers of aerobic heterotrophic, sulfate-reducing, nitrate-reducing, citrate-utilizing, and diesel-degrading bacteria. Additionally, the disappearance of total petroleum hydrocarbons was determined in microcosms containing subsurface materials that were amended with diesel fuel. Results revealed that microbes capable of utilizing diesel and diesel combustion products were present in the subsurface in both the walls and the invert of the tunnel. The abundance of specific bacterial types in the tunnel invert, a perturbed environment, was greater than that observed in the tunnel wall. Few trends of microbial distribution either into the tunnel wall or the invert were noted with the exception of aerobic heterotrophic abundance which increased with depth into the wall and decreased with depth into the invert. No correlation between microbiota and a specific introduced chemical species have yet been determined. The potential for microbial contamination of the tunnel wall during sampling was determined to be negligible by the use of fluorescently labeled latex spheres ( $1 \mu \mathrm{m}$ in dia.) as tracers. Results indicate that additional investigations might be needed to examine the microbiota and their possible impacts on the geology and geochemistry of the subsurface, both indigenous microbiota and 


\section{DISCLAIMER}

Portions of this document may be illegible in electronic image products. Images are produced from the best available original document. 
those microorganisms that will likely be introduced by anthropogenic activity associated with the construction of a high-level waste repository.

\section{INTRODUCTION}

Viable microbes have been recovered from the subsurface at depths to $450 \mathrm{~m}$ in the volcanic tuffs of Rainier Mesa, Nevada Test Site ${ }^{1-4}$. Currently, little is known about the microbial ecology of Rainier Mesa or of the subsurface in general. Thus, questions arise regarding the importance of microbiota in the biogeochemical cycling of elements, interactions with metals, and their survival, corrosive and degradative potentials, especially with regard to the long-term disposal of nuclear waste in deep geological formations ${ }^{5-8}$. Rainier Mesa, provides an ideal opportunity to sample for subsurface microbiology because rock can be taken from the walls of extant tunnel systems at depths to $450 \mathrm{~m}$ without the costs and concerns associated with drilling operations ${ }^{1,2,9}$. Another practical advantage of microbiological investigations in Rainier Mesa is that they may serve as analogs for microbial processes at the potential Yucca Mountain nuclear waste repository and the development of experimental protocols at the Exploratory Studies Facility (ESF, Yucca Mountain) in that both environments have geological similarities.

It is important to consider in situ microbial communities as well as the effects of anthropogenic introduction of bacteria and nutrient sources when 
modeling the integrity of a repository over long time periods. Construction of a repository is expected to impact indigenous bacteria and introduce microbiota to the subsurface. For example, sampling and sample handling perturbations have been shown to increase the abundance and stimulate the activity of subsurface microbial communities ${ }^{10,11}$. These phenomena may occur because physical redistribution of materials may make compounds essential for bacterial resuscitation or growth more bioavailable ${ }^{9-12}$. Additionally, substances may be introduced into the subsurface that may serve as bacterial nutrients (or inhibitors), e.g., water, oxygen, fuel exhaust, etc.

The purpose of this investigation was primarily to better understand the impact of diesel exhaust on subsurface microbiota because diesel-powered engines may be employed during the construction of the ESF. Many components of diesel combustion such as short chain acids, sulfates, and nitrates ${ }^{13-15}$, and the components of diesel fuel itself, can be used by microbes as carbon and energy sources ${ }^{16}$. Thus, the activity of autochthonous subsurface microbes (or allocthonous microbiota) will likely be altered by the introduction of these compounds, and geochemical parameters of the environment may be impacted. A secondary purpose was to evaluate the sampling procedure and tracer analysis for potential future use in the microbial studies of the ESF. Fluorescently labeled latex microspheres were painted on the tunnel walls and were examined from underlying rock faces to determine the potential for contamination during sampling. 
The subsurface tunnels of Rainier Mesa proved an ideal location to investigate the impacts of diesel exhaust on microbiota because diesel-burning locomotives have been active (intermittently) in some tunnel shafts since 1964 . Microbiota were sampled from the surface of a tunnel wall in an area that was impacted by diesel exhaust and cores were extruded from the tunnel invert in the same area. The tunnel invert material represented an environment that had been heavily perturbed, both physically by anthropogenic activity since tunnel construction and by periodic water flux. Numbers of culturable aerobic heterotrophic, diesel-degrading, citrate-utilizing, sulfate-reducing, and denitrifying bacteria were enumerated at all sample locations to determine the abundance of microorganisms capable of utilizing diesel and diesel combustion products. Diversity, evenness of distribution, total cell numbers, and the abundances of particular microbial types were determined from samples taken at various depths into the tunnel walls and into the invert to discern possible trends in microbial distribution. To determine the potential for diesel degradation, microcosms containing sample materials were incubated with diesel fuel and the disappearance of total petroleum hydrocarbons (TPHs) was determined for each sample.

\section{MATERIALS AND METHODS}

\section{Sampling and Sample Locations}

Samples were taken from the left rib of tunnel U12n approximately 500 
$\mathrm{m}(19+00 \mathrm{ft})$ from the portal. The ambient temperature was approximately $13^{\circ} \mathrm{C}$. Samples were taken from the wall at the height of exhaust pipes of diesel-combustion locomotives and at a location where the trains were often left idling. Black deposits could be seen on the tunnel wall in this area. Approximately $100 \mathrm{~g}$ of rock was taken from wall surfaces approximately $10 \mathrm{x}$ $10 \mathrm{~cm}$ in area. Triplicate samples were taken from the exposed surface of the wall and at two depths: approximately 1 and $3 \mathrm{~cm}$ (Figure 1). The samples were collected by aseptically chipping rock into sterile containers as previously described ${ }^{1-3}$. Samples were rapidly transported in coolers containing ice to minimize storage related effects ${ }^{11}$, and microbiological analysis was initiated immediately upon return to the laboratory (less than $6 \mathrm{~h}$ from the time of sample procurement).

Three, approximately $10 \times 10 \mathrm{~cm}$ surfaces of the tunnel wall, were painted with one each of three kinds of labeled $1.0 \mu \mathrm{m}$ latex microspheres (Fluorsebrite carboxy yellow/green, Polyscience; blue and yellow/green colored, polystyrene latex surface free, IDC, Portland Ore.) Microbead rock faces were located approximately $1 \mathrm{~m}$ from the microbiological samples, in the same tunnel bed, and samples were taken at the same depths and in the same manner as described above to determine the potential for contamination during sampling.

Three floor samples were taken by pounding sterile $15 \mathrm{~cm}$ core barrels 
$(6 \mathrm{~cm} \mathrm{dia.)}$ into the curnel invert at the same location that the wall samples were collected. Cores were wrapped in sterile foil and were transported to laboratory as described above. The core material was extruded in the laboratory after first aseptically removing the top $2 \mathrm{~cm}$ of material. The unconsolidated material from the top $(3-5 \mathrm{~cm})$, middle $(6-9 \mathrm{~cm})$ and bottom $(11-14 \mathrm{~cm})$ was used for microbiological analysis (Figure 2).

Several techniques were used to obtain samples for inorganic analysis. Surface deposit samples were collected both as peels and consolidated samples with water glass to attach the surface firmly to the underlying rock. Powder samples were taken from the floor, and at the contact between the floor and the wall where a dark band of deposit was observed. A few cores were obtained using a battery powered drill and water as a lubricant. A large rock weighing roughly $13 \mathrm{~kg}$, and displaying a thick surface deposit was also removed and transported to the laboratory in one piece.

\section{Sample Analysis}

Rock and invert material were aseptically ground in sterile mortars and pestles, transferred to sterile containers, and homogenized before sub-portions were taken to determine gravimetric dry weight, total organic carbon, total petroleum hydrocarbon degradation, direct bacterial count, and to enumerate specific bacterial types (culturable aerobic heterotrophic, sulfate-reducing, and nitrate-reducing bacteria, and the numbers of bacteria capable of utilizing citrate 
or diesel as a sole carbon source). Microcosms used to determine TPH degradation were prepared with $5 \mathrm{~g}$ of homogenized rock and $50 \mu \mathrm{l}$ diesel in sealed serum vials. Acetone was used to stop the reactions after $30 \mathrm{~d}$ incubation at room temperature (ca. $24^{\circ} \mathrm{C}$ ) and to extract the diesel. Replicate samples were sacrificed at time zero to determine extraction efficiencies. Portions of the diesel/acetone mixture $(0.5 \mathrm{ml})$ were removed, extracted in $100 \mathrm{ml}$ deionized water to separate diesel and acetone, and the remaining diesel was extracted into $1 \mathrm{ml}$ hexane (Sigma). Samples were injected into a Hewlett Packard 5890 gas chromatograph [Polydimethyl diphenyl (5\%) siloxanes column (Alltech, RSL200) with initial and final temperature of 50 and $260^{\circ} \mathrm{C}$ respectively, and a ramp of $\left.15^{\circ} \mathrm{C} / \mathrm{min}\right)$. The TPH values were determined by integration of the peaks of compounds with retention times from 5 to $20 \mathrm{~min}$ and comparison to a standard curve.

Portions of rock were made into $1: 10 \mathrm{wt} / \mathrm{vol}$ slurries with filter sterilized $0.1 \%$ sodium pyrophosphate and were shaken for $1 \mathrm{~h}$ at approximately 150 rpm. Subsamples of slurry were used to determine total counts, culturable aerobic heterotrophic counts and for most probable number (MPN) enumerations of specific microbial types ${ }^{17}$.

For direct counts, portions of prepared slurries $(9 \mathrm{ml})$ were fixed with $135 \mu \mathrm{l}$ of filter-sterilized $(0.2 \mu \mathrm{m})$ formaldehyde and $1 \mathrm{ml}$ of filter-sterilized noble agar. Smears were prepared by evenly distributing $5 \mu \mathrm{l}$ portions of fixed slurry into $1 \mathrm{~cm}$ in diameter circles drawn on clean glass slides, and were air- 
dried before staining. A $0.01 \%$ acridine orange solution containing $5 \mu \mathrm{g} / \mathrm{ml}$ 4'-6-diamidino-2-phenylindole (DAPI; Sigma) was flooded onto smears and allowed to stand for $2 \mathrm{~min}$. Smears were rinsed with approximately $20 \mathrm{ml}$ of $1 \mathrm{M} \mathrm{NaCl}$ and deionized $\mathrm{H}_{2} \mathrm{O}$ (filter-sterilized solutions). A drop of oil was placed on smears after they were completely dry, a cover slip was added, and another drop of oil was placed on the cover slip for viewing at $1000 \mathrm{x}$ magnification under oil immersion. Twenty fields or 200 cells were counted from each smear with a Nikon Optiphot epifluorescence microscope fitted with a Nikon Fluor 100 lens, a $100 \mathrm{~W}$ mercury bulb, and filter blocks (UV-B and UV-1A).

To determine numbers of culturable heterotrophs, serial dilutions of unfixed slurry were made in deionized $\mathrm{H}_{2} \mathrm{O}$ and were spread-plated onto $\mathrm{R} 2 \mathrm{~A}$ agar $^{1}$ (Difco). Shannon diversity and evenness indices ${ }^{16}$ were determined from R2A spread plates as previously described ${ }^{3}$. One of each colony morphotype was selected for purification from wall samples. Comparison of colonies by morphotype has been shown to be a reliable method for the selection of bacteria from subsurface tunnel samples that were related at $\leq$ the genus level ${ }^{18}$. All colony types were compared to determine if certain bacterial types were recovered from more than one replicate or rock face and to enumerate numbers of actinomycetes, fungi and polymer producing bacteria.

To determine most probable numbers (MPNs) of diesel-degrading, sulfate-reducing (SRB), and nitrate-reducing (NRB) bacteria, 1000, 100 and 10 
$\mu \mathrm{l}$ portions of slurries were used to inoculate sets of 5-tube MPN media. Diesel degradation MPN tubes contained $50 \mu$ of diesel added to $5 \mathrm{ml}$ of Bushnell Haus broth (Difco) containing $1 \mathrm{mg} / \mathrm{L}$ filter-sterilized resazurin ${ }^{19}$. Tubes were considered positive if they turned pink or clear compared to purple controls ${ }^{19}$. Tubes containing SRB medium ${ }^{20}$ were scored as positive if they were black in color as compared to uninoculated controls. Nitrate-reducing bacteria were determined in $\mathrm{R} 2 \mathrm{~B}$ broth containing $0.1 \% \mathrm{KNO}_{3}$ as previously described ${ }^{2}$. To determine the MPN of bacteria capable of using citrate as a sole carbon source, $10 \mu \mathrm{l}$ of slurry and $1: 10$ serial dilutions in deionized $\mathrm{H}_{2} \mathrm{O}$ were struck onto slants (five tubes of each dilution) of Simmon's citrate agar (Difco). A color change from green to blue indicated a positive reaction. All MPN tests were incubated for $30 \mathrm{~d}$ at room temperature (approximately $24^{\circ} \mathrm{C}$ ) before reading. All incubations were conducted under aerobic conditions, except SRB tubes which were incubated in a reducing atmosphere.

Samples containing microspheres were aseptically ground, homogenized and made into 1:10 wt/vol slurries with filter-sterilized deionized water. Five microliter portions of slurries were evenly distributed into circles drawn on clean slides. Slides were air dried, and were viewed and counted as described above for direct counting.

A variety of techniques were used to perform qualitative and semiquantitative chemical analyses on the samples. A Hitachi-S-800 scanning electron micorscope (SEM) equipped with a Kevex 8000 energy-dispersive 
$x$-ray spectrometer (EDS) was used to perform electron optical imaging and determine elemental spatial-distribution. Backscattered eiectron imaging, which is sensitive to atomic number $(Z)$ proved to be a valuable technique to search for heavy metal components. Fourier transform infrared spectroscopy (FTIR) was used to determine the organic, $\mathrm{NO}_{\mathrm{x}}$ and $\mathrm{SO}_{\mathrm{x}}$ compounds. Secondary ion mass spectrometry (SIMS) was used to detect aromatics. X-ray fluorescence spectrometry (XRF), conducted with a Siemens 303 wavelength dispersive spectrometer, was used to perform elemental analysis. X-ray diffraction (XRD) was used to determine the mineralogy of the samples. Percent total carbon was determined with a Leco induction furnace. Carbonate carbon was determined by titration of $\mathrm{CO}_{2}$ from an acid digest of the sample, and total organic carbon (TOC) was determined by subtraction of carbonate carbon from total carbon. These techniques are described in more detail in Meike, et al. ${ }^{21}$.

\section{RESULTS}

Enumerations of latex microspheres at the three sample depths (Figure 3) indicated that introduction of $1 \mu \mathrm{m}$ particles into the tunnel wall by sampling procedures was unlikely. All three types of spheres demonstrated a dramatic percent decrease in abundance after the surface sampling face. The scale on the graph in Figure 3 precludes direct observation of significant decreases in sphere abundance between the faces 1 and $3 \mathrm{~cm}$, but statistically significant differences 
were determined between those faces as well.

Data concerning the direct counts and the numbers of culturable aerobic heterotrophic bacteria, recovered from wall and invert samples, are presented in Figures 4 and 5. Culturable (Fig. 4) and total cells (Fig. 5) were more numerous in the core samples ( $25.8 \%$ moisture) as compared to the wall samples ( $4.9 \%$ moisture). Abundance of culturable cells increased with depth into the tunnel wall (Fig. 4A) and decreased with depth into the tunnel floor (Fig. 4B). The error associated with direct counting was high, probably in part due to the autofluorescing nature of the rock samples, and precluded the observation of trends in total cell counts at sampling distances into the tunnel invert (Fig. 5). However, a decrease in total cell number was seen between the surface wall sample and the two subsequent sampling faces. Total cell counts were higher than culturable cells counts in both the wall and invert samples. The largest discrepancy was noted in the wall samples; approximately $10^{4}$ culturable cells and $10^{8}$ total cells/g dry wt of rock.

Percent total organic carbon (TOC) was significantly higher in the invert samples than in the wall samples (Fig. 6). Interestingly, TOC showed a decreasing trend both into the tunnel floor and into the wall and correlated directly with aerobic heterotrophic counts in the invert $\left(r^{2}=0.71\right)$ and inversely in the wall $\left(r^{2}=0.79\right)$. It is important to note that black deposits were observed on the face of the tunnel wall but were not seen on subsequent rock faces. 
Although the composition of the black deposits was not determined, if the deposits were elemental carbon (soot) they would be reflected in the percent TOC by the assay used.

Differences in diversity and evenness could not be demonstrated between invert and wall samples, exclusive of the surface wall face which had a lower diversity (2.51) than that in the shallowest core samples (3.51). Additionally, trends of distribution into the tunnel wall or invert were not discerned in either invert or wall samples based on diversity and evenness indices (data not shown). However, analysis of one of each individual colony morphotype from wall samples demonstrated that although the numbers and patterns of distribution of distinct colony types in samples may have been similar, the specific colony types that were recovered were often quite different from each other, even among replicates of a single sample face or depth (Table I). Only 8,15 , and $5 \%$ of colony types recovered from the three replicate samples taken within a single wall face were found in more than one replicate. The number of unique actinomycete colony types that were recovered from the wall samples ranged from 15 to 25 , and fungi were only recovered from the first two rock faces. The numbers of polymer forming bacterial colonies did not show a trend into the tunnel wall $(4,3$ and 4 types from the surface, 1 and $3 \mathrm{~cm}$, respectively), and each polymer forming morphotype was unique from others in some aspect, i.e., relative polymer production, and/or colony color, size or shape. In the wall samples, most colony types were recovered from only a single rock face 
(Table II). Most of the isolates that were recovered from multiple rock faces were from the 1 and $3 \mathrm{~cm}$ faces.

The MPN enumeration of SRB, NRB, diesel-degrading and citrateutilizing bacteria are presented in Table III. Most types of bacteria were more abundant in invert samples as compared to wall samples. A decreasing trend in distribution in citrate utilizing bacteria with depth was noted in the invert samples, while other MPN tests showed no trend. In the wall samples, the second face had higher numbers of citrate-utilizing bacteria and fewer bacteria capable of reducing $\mathrm{NO}_{3}^{-}$to $\mathrm{NO}_{2}$.

The MPN enumeration demonstrated that more bacteria capable of degrading diesel fuel were present in the invert samples as compared to wall samples (Table III). No statistically significant trends in distribution were noted into the invert or into the tunnel walls, but the existence of a trend in the invert can not be ruled out as all samples exceeded the upper detection limit of the test. Microcosms, used to measure the disappearance of diesel, did not demonstrate a decrease in diesel fuel after $30 \mathrm{~d}$ incubation as compared to fixed controls. It is important to note that in the microcosms only diesel fuel was added, while the MPN tests for diesel degrading bacteria contained a medium of mineral salts containing nitrogen and phosphate.

Concentrations of $\mathrm{Ba}, \mathrm{Ti}, \mathrm{S}$, and $\mathrm{Ca}$ were greater in the surface deposit than in the rock at depth $(-2.5 \mathrm{~cm}$ from the tunnel surface). Figure 7 illustrates the variation in $\mathrm{Ba}, \mathrm{Ti}$ and $\mathrm{S}$ concentrations with depth in the rock cores. The 
data represent analyses of two rock cores and a single analysis of a surface deposit. Although all of these elements are related to diesel exhaust in the literature increases in $\mathrm{S}, \mathrm{Ca}$, and even Ba may also be related to tunnel respiration (the process of the transportation of dissolved species to the tunnel wall where evaporation occurs, leaving a precipitate, e.g., the Ca could drive from a $\mathrm{CaCO}_{3}$ deposit). The presence of other metals that have been associated with diesel exhaust analyses in the literature $(\mathrm{As}, \mathrm{Cu}, \mathrm{Pb}, \mathrm{Bi}, \mathrm{Mo}, \mathrm{Mn}, \mathrm{Pt}$, and P) were detected in some surface deposit samples (data not shown). The variability is related to trace concentrations (often near the detection limit of the instrument), but may also suggest heterogeneity of the exhaust deposit and, in some cases, a source other than diesel exhaust (e. g., detergent, minute paint. spatters, flakes of coating materials). Other elements detected (Si, Fe, $\mathrm{Zn}, \mathrm{Nb}$, $\mathrm{Rb}, \mathrm{K}$ ) did not show an arguable trend with rock depth beyond the analytical error. The measured concentrations of $\mathrm{Cr}$ and $\mathrm{Ni}$, also associated with diesel exhaust, increased at depth. However, with the exception of $\mathrm{Ba}$, the absolute concentrations of elements that can be directly associated with diesel exhaust are quite low. A minimal increase in hydrocarbon content was detected.

\section{DISCUSSION}

The use of microspheres provided a means to determine the impact of sampling procedures on the procurement of representative subsurface material 
for microbiological analyses. Researchers in the Deep subsurface Microbiology Program currently endorse the use of tracers, such as the use of microspheres to assure sample integrity ${ }^{22-23}$. We successfully applied the use of microspheres as tracers to sampling within the tunnel systems. The results demonstrate that transport of $1 \mu \mathrm{m}$ sized microspheres is greatly reduced after removing just 1 $\mathrm{cm}$ of surface rock (Fig. 3) and thus, the probability of the introduction of exogenous microbes during sampling at greater depths is limited.

In previous microbiological research where samples were obtained at depths into the tunnel walls $>5 \mathrm{~cm}$, fungi served as an indicator of microbial contamination during sampling. It is interesting to note that fungi, recovered here in low abundance on the surface and at $1 \mathrm{~cm}$ into the tunnel wall, were not recovered in samples taken at $3 \mathrm{~cm}$ into the wall rock, and augmented assurance of uncompromised samples by acting as a fortuitous tracer.

Direct counts, though difficult to measure in the autofluorescing tuffs of Rainier Mesa, were consistently greater than culturable aerobic heterotrophic bacterial counts and MPN estimates of microbial abundance. The discrepancy between culturable counts and direct counts (Fig. 3) is due to non-culturable cells, either dead, dormant or viable-but-non-culturable cells (VBNC). It would not be surprising to find large numbers of dead or dormant cells in wall samples, because zeolitized tuffs experience little or no nutrient flux in unfractured areas ${ }^{1,2,24}$. The use of phospholipid fatty acid and diglyceride fatty acid contents in comparison with acridine orange direct counting of subsurface 
samples of zeolitized rock from Rainier Mesa has indicated that this may be the case $^{25}$. However, VBNC are also common in natural environments ${ }^{26}$ and their presence can not be ruled out in the subsurface of Rainier Mesa ${ }^{11,25}$. More investigation is needed in this area to determine abundance, distribution and in situ functions of non-culturable cell populations as well as potential for activity if growth requirements were met, because anthropogenic activity associated with repository construction may provide the necessary environmental conditions thereby stimulating currently dormant microbial populations.

Higher total cell counts were determined in the cored invert material as compared to the wall samples (Fig. 5). The invert samples were unconsolidated, had a higher moisture content, higher total organic content, and had been periodically perturbed by anthropogenic activities since original tunnel construction. All of these factors may have influenced the invert environment such that it supported greater bacterial numbers. Geological and microbiological parameters that have been correlative in the deep subsurface include higher moisture, permeability, and organic carbon content with increased bacterial numbers ${ }^{4,27,28}$, although these correlations have not been previously demonstrated in the analysis of tuffaceous rock from Rainier Mesa ${ }^{29}$. Perturbations have been shown to increase microbial abundance and activity in surface and subsurface environments ${ }^{10,30,31}$, including samples from Rainier Mesa $^{9,11,12,25}$. More information concerning impacts such as these on in situ 
subsurface microbiota will be needed to adequately model long term effects of microbiota on repository integrity.

TOC measurements demonstrate a decreasing trend both into the wall and invert with depth from the tunnel surface. It should be noted however, that elemental carbon may have been included in TOC analysis because it could not be excluded from the total carbon determination. Blackened material was observed on the wall surface, but not on faces created at depth into the tunnel wall. Further analysis would be needed to determine if this material was a major constituent of what we measured as TOC, because elemental carbon is not bioavailable.

The negative correlation between TOC and microbial abundance in the wall samples suggests that components of the surface may have toxic effects on microbiota. Inorganic chemical analyses were made on the surface layer and at $2-3 \mathrm{~cm}$ depth into the tunnel wall (sampled within $1 \mathrm{~m}$ of the microbiological samples) and revealed that $\mathrm{Ba}$ and $\mathrm{S}$ concentrations decreased with depth ${ }^{21}$. However, no correlation between any introduced chemical species and microbiota has yet been established.

Measures of microbial communities (diversity, evenness of distribution, and in most cases direct counts) did not show distinct differences between samples. However, heterogeneity was noted in the abundance and types of heterotrophic bacteria that were recovered. This was not surprising because heterogeneity has been noted on a larger scale in this and other subsurface 
environments ${ }^{2,3,10,32,33}$. The wall rock appeared more homogeneous in microbial composition after the immediate surface was removed as evidenced by the increased number of colony types that were in common between the 1 and $3 \mathrm{~cm}$ rock faces. However, the probability of finding common organisms may have been due to the recovery of higher numbers of culturable organisms from those faces as compared to the surface. MPN analyses, which enumerate functional groups of microorganisms, demonstrated few trends in microbial distribution within the wall samples. More complete characterization of heterotrophic isolates may determine that they fulfill similar niches (besides heterotrophy) although they differ in appearance. Further, it is important to stress that these are not in situ measures of microbial activity but reflect the organisms that were cultivated under enriching conditions. Microbial heterogeneity is an issue that needs to be addressed in future site characterization.

Although a decrease in the amount of diesel added to the microcosms was not demonstrated, diesel-degrading MPN media tested positive. Further experimentation would be needed to determine if the oxidative activity in the MPN tubes was exclusively a result of diesel degradation or if the activity was due to nutrients provided in the inoculum, bacteria degrading each other, or gaseous compounds. The addition of a mineral salts medium to microcosms could also aid in determining if the lack of diesel degradation as measured by TPH was due to a limiting nutrient such as a phosphate or nitrogen source. No 
studies have been done within the tunnel systems to determine limiting nutrients. These experiments will be important in understanding the effects of perturbations on microbial communities.

\section{SUMMARY}

Two types of bacteria present within the tunnel system included polymer-forming and sulfate-reducing bacteria, which are known to play roles in the corrosion process ${ }^{8,34,35}$. Likewise, bacteria capable of degrading diesel and diesel combustion products were present. The presence of these microbiota, whether introduced or naturally occurring, is important because the activity of one group of microorganisms may influence the activity of, or select for another group, setting off a chain reaction of complex events ${ }^{5,33-38}$. However, issues concerning the survival, activity, and interaction of subsurface microbes in the presence of each other and their subsurface environment are as yet relatively unknown with respecto the longevity of waste packages and construction materials in a nuclear repository.

\section{ACKNOWLEDGEMENTS}

We thank S. Perera and B. Pitonzo for help with initial sample workups and M. Alai for arrangin inorganic sample analyses and sampling procedures. We thank A. Simmons, M. Owens, R. Pletcher K. Kinter, A. 
Mitchel, N. Elkins, and B. Harris-West for arranging sampling at $\mathrm{N}$-tunnel.

This work was performed under the auspices of the U. S. Department of Energy by Lawrence Livermore National Laboratory under Contract No. W-7405-Eng48 in cooperation with Yucca Mountain Site Characterization Project (YMSCP) participants as a part of the Civilian Radioactive Waste Management Program. YMSCP is managed by the Yucca Mountain Site Characterization Project Office of the U. S. Department of Energy, Las Vegas, Nevada.

\section{REFERENCES}

1. P. S. Amy, D. L. Haldeman, D. Ringelberg, D. H. Hall, and C. Russell, Appl. Environ. Microbiol. 58, 3367 (1992).

2. D. L. Haldeman, and P. S. Amy, Microb. Ecol. 25, 183 (1993).

3. D. L. Haldeman, P. S. Amy, D. Ringelberg, and D. C. White, Microb. Ecol. 26, 145 (1993)

4. T. L. Kieft, P. S. Amy, F. J. Brockman, J. K. Fredrickson, B. N. Bjornstad, and L. L. Rosacker, Microb. Ecol. 26, 59 (1993).

5. R. Bachofen, Experentia 47, 583 (1991).

6. L. D. Birch, and R. Bachofen, Soil Biochemistry. 6, 483 (1990).

7. G. M. Gadd, Experentia. 46, 834(1990)

8. J. M. West, N. Christofi, and I. G. McKinley, Radioactive Waste Management and the Nuclear Fuel Cycle 6, 79 (1985).

9. D. L. Haldeman, P. S. Amy, C. Russell, and R. Jacobson, J. 
Microbiol. Meth. 21305 (1995).

10. F. J. Brockman, T. L. Kieft, J. K. Fredrickson, B. N. Bjornstad, S. W. Li, W. Spangenburg, and P. E. Long, Microb. Ecol. 23, 279(1992).

11. D. L. Haldeman, P. S. Amy, D. Ringelberg, and D. C. White, Appl. Environ. Microbiol. 60, 2697 (1994).

12. J. K. Fredrickson, S. W. Li, F. J. Brockman, D. L. Haldeman, P. S. Amy, and D. L. Balkwill, J. Microbiol. Meth. 21, (1995)

13. Air Pollution Manual, Part I. Evaluation 2 nd Ed. (American Industrial Hygiene Association, 1972) p. 21 and 23

14. D. H. Carlson, J. H. Johnson, S. T. Bagley, and L. D. Gratz, Appl. Environ. And Occupational Hygiene, In press

15. J. H. Daniel, Jr., Diesels in underground mines: Measurement and control of particulate emissions. (Proceedings: Bureau of Mines. Information and Technology Transfer Seminar, Minneapolis, MN 1992) Sept. 29-30. pp. $121-128$.

16. R. M. Atlas, and R. Bartha, Microbial ecology fundamentals and applications (The Benjamin/Cummings Publishing Company, Inc., Redwood City, California, 1992) p. 142.

17. M. Alexander. Methods of Soil Analysis, Part 2: Chemical and Microbiological Properties (C. A. Black (ed.). American Society of Agronomy, 
Madison Wis., 1965) pp. 1467-1472.

18. D. L. Haldeman, and P. S. Amy, Appl. Environ. Microbiol. 59, 933 (1993).

19. H. G. Song, and R. Bartha, Appl. Environ. Microbiol. 56, 646 (1990).

20. R. M. Atlas, Handbook of microbiological media (L. C. Parks (Ed.) CRC Press, Boca Raton, FL, 1993) p. 856.

21. A. Meike, W. L. Bourcier, M. Alai, D. L. Haldeman, P. S. Amy, T. Lagadinos, and L. Hersman, (Yucca Mountain Project MOL73, September $30,1994)$.

22. F. S. Colwell, G. J. Stormberg, T. J., Phelps, S. A. Birnbaum, J. McKinley, S. A. Rawson, C. Verveka, S. Goodwin, P. E. Long, B. F. Russell, T. Garland, D. Thompson, P. Skinner, and S. Grover, J. Microbiol. Meth. 15, 279 (1992).

23. B. F. Russell, T. J. Phelps, W. T. Griffin, and K. Sargent, Groundwater Monitoring Rev. 12,96 (1992).

24. P. S. Amy, C. D., Durham, D. H. Hall, and D. L. Haldeman, Curr. Microbiol. 26, 345 (1993).

25. D. L. Haldeman, P. S. Amy, D. Ringelberg, D. C. White, R. E. Garen, and W. C. Ghiorse, FEMS Microb. Ecol. 17: 27 (1995)

26. D. B. Rozak, and R. R. Colwell, Microbiol. Rev. 51, 365 (1987). 
27. J. K. Fredrickson, T. R. Garland, R. J. Hicks, J. M. Thomas, S. W. Li, and K. M. McFadden, Geomicrobiol. J. 7, 53 (1989).

28. K. J. Severson, D. L. Johnstone, C. K. Keller, and B. D. Wood, Geomicrobiol. J. 9, 197 (1991).

29. C. R. Russell, R. J. Jacobson, D. L. Haldeman, and P. S. Amy, Geomicrobiol. J. 12, 37 (1994)

30. E. T. Craswell, and S. A. Waring, Soil Biol. Biochem. 4, 435 (1972).

31. A. D. Rovira, and E. L. Greacen, E. L. Aust. J. Agric. Res. 8, 659 (1957).

32. F. S. Colwell, Appl. Environ. Microbiol. 55, 2420 (1989). 33. D. L. Balkwill, J. K. Fredrickson, and J. M. Thomas, Appl. Environ. Microbiol. 55, 1058 (1989).

34. D. A. Jones, Principles and prevention of corrosion. (Macmillan Publishing Co. New York, NY. 1992) pp. 371-380.

35. A. McCabe, Experentia 46, 779 (1990).

36. A. Rosevear, AEA Environment and Energy NSS/R26, (1991).

37. S. Stroes-Gascoyne, Atomic Energy of Canada Limited, Rpt AECL9574 (1989).

38. J. M. West, N. Christofi, J. C. Philip, and S. C. Arme, U. K. Dept. of Env. Rpt DOE/RW/85-116; CEC Rpt. EUR 10405 EN (1986). 


\section{FIGURE LEGENDS}

Figure 1. Schematic demonstrating locations of replicate samples (A, B, and C) taken from three rock faces (surface and at depths of 1 and $3 \mathrm{~cm}$ ) into the tunnel wall. Relative locations where the three invert cores were collected are indicated by spheres.

Figure 2. Schematic demonstrating locations (A, B, and C) of replicate cores taken from the tunnel floor. Subsection of the cores represent the three sampling depths $(3-5,6-9$ and $11-14 \mathrm{~cm}$ from the invert surface).

Figure 3. Distribution of latex spheres into the tunnel walls; $\Delta=$ Polyscience yellow/green, $O=$ IDC blue, $\square=$ IDC yellow green.

Figure 4. Culturable cell counts into the tunnel wall (a) and into the invert (b). Figure 5. Total cell counts at depths into the tunnel wall and invert.

Figure 6. Percent of total organic carbon found at sample depths into the tunnel walls or into the invert.

Figure 7. Variations of $\mathrm{Ba}, \mathrm{Ti}$, and $\mathrm{S}$ concentrations with depth into the tunnel wall are not plotted to scale in order to illustrae surface deposit chemistry (WD) and rock surface chemistry $(S)$. The numbers $1-6$ represent roughly $0.5 \mathrm{~cm}$ intervals along the rock cores. 
Table I. Number of Bacterial Types that Were Common within a Set of Replicates.

Sample Faces

\begin{tabular}{|c|c|c|c|}
\hline & Surface & $-1 \mathrm{~cm}$ & $-3 \mathrm{~cm}$ \\
\hline $\begin{array}{c}\text { Ratio of Bacterial } \\
\text { Types }^{\mathrm{a}}\end{array}$ & $4 / 47$ & $9 / 59$ & $2 / 41$ \\
\hline Percentage $^{\mathrm{b}}$ & 8 & 15 & 5 \\
\hline
\end{tabular}

${ }^{2}$ Number of bacterial types found in more than one replicate/ total number of bacterial types in the three replicates.

${ }^{b}$ Percent of bacterial types found in more than one replicate.

Table II. Distribution of Microbial Types Recovered from Multiple Rock Faces

\begin{tabular}{|c|c|c|c|c|}
\hline & $\begin{array}{c}\text { Surface and 1 } \\
\text { cm Faces }\end{array}$ & $\begin{array}{c}1 \text { and } 3 \mathrm{~cm} \\
\text { Faces }\end{array}$ & $\begin{array}{c}2 \text { and } 3 \mathrm{~cm} \\
\text { Faces }\end{array}$ & All Faces \\
\hline $\begin{array}{c}\text { Number of Similar } \\
\text { Bacterial Types }\end{array}$ & $3 / 104$ & $2 / 87$ & $11 / 90$ & $2 / 131$ \\
\hline Percentage $^{\mathrm{b}}$ & 3 & 2 & 12 & 2 \\
\hline
\end{tabular}

a Number of similar bacterial types that were recovered from more than one rock face/ total number of bacteria recovered from those faces.

${ }^{b}$ Percentage of bacteria types found in multiple rock faces. 
Table III. Most Probable Number Enumerations of Specific Bacterial Types ${ }^{\mathrm{a}}$

Bacterial Types (Cells/g wwt)

\begin{tabular}{|l|c|c|c|c|c|}
\hline $\begin{array}{c}\text { Sample } \\
\text { Designations } \\
\text { (Depth in cm) }\end{array}$ & $\begin{array}{c}\text { Sulfate- } \\
\text { Reducing } \\
\text { Bacteria }\end{array}$ & $\begin{array}{c}\text { Nitrate- } \\
\text { Reducing } \\
\text { Bacteria } \\
\text { (NO3->NO2) }\end{array}$ & $\begin{array}{c}\text { Nitrate- } \\
\text { Reducing } \\
\text { Bacteria } \\
\text { (NO3--->N2) }\end{array}$ & $\begin{array}{c}\text { Diesel } \\
\text { Degrading } \\
\text { Bacteria }\end{array}$ & $\begin{array}{c}\text { Citrate } \\
\text { Utilizing } \\
\text { Bacteria }\end{array}$ \\
\hline Invert (3-5) & 13.50 & 25.33 & 360.00 & $>1600$ & 10067.00 \\
\hline Invert (6-9) & 15.33 & 2.40 & 793.33 & $>1600$ & 3733.33 \\
\hline Iuvert (11-14) & 12.25 & $1.80^{\mathrm{b}}$ & $1210^{\mathrm{c}}$ & $>1600$ & 1800.00 \\
\hline Wall (surface) & $\mathrm{BLD}$ & 87.00 & $\mathrm{BLD}$ & 19.67 & $\mathrm{BLD}$ \\
\hline Wall ( 1) & BLD & 23.33 & $1.80^{\mathrm{b}}$ & 20.67 & $450.00^{\mathrm{c}}$ \\
\hline Wall ( 3) & BLD & 85.33 & $5.75^{\mathrm{e}}$ & 29.60 & $200.00^{\mathrm{c}}$ \\
\hline
\end{tabular}

Average MPN values are presented.

b Two of the three replicates had numbers below the limit of detection

c Two of the three replicates had numbers greater than the detection limit $(>1600)$. A conservative average was estimated using 1600 for the values of those replicates.

d BLD designates numbers below the limit of detection ( $<1.8$ cells $/ g$ wwt).

c One of the three replicates had numbers below the limit of detection 


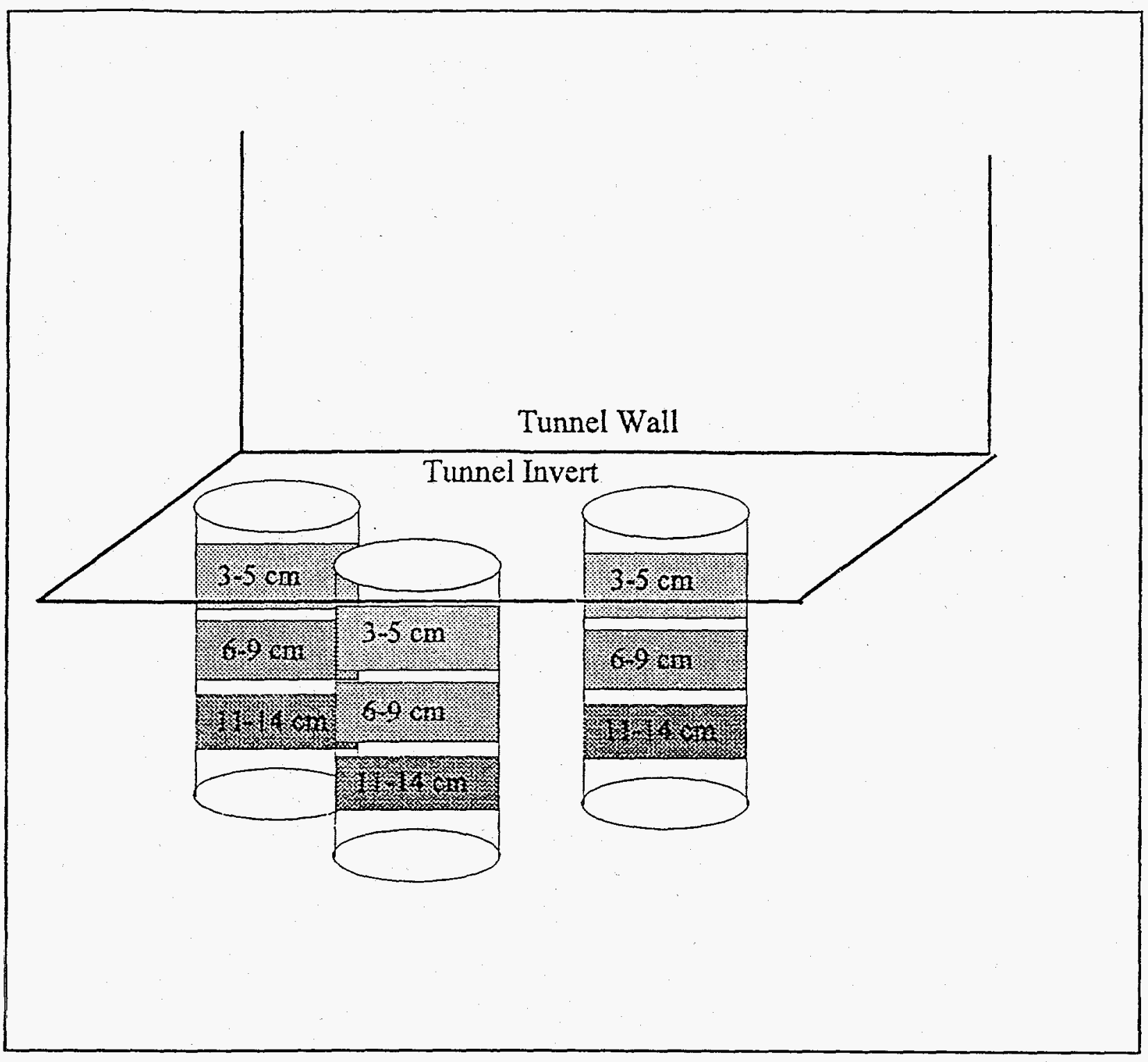



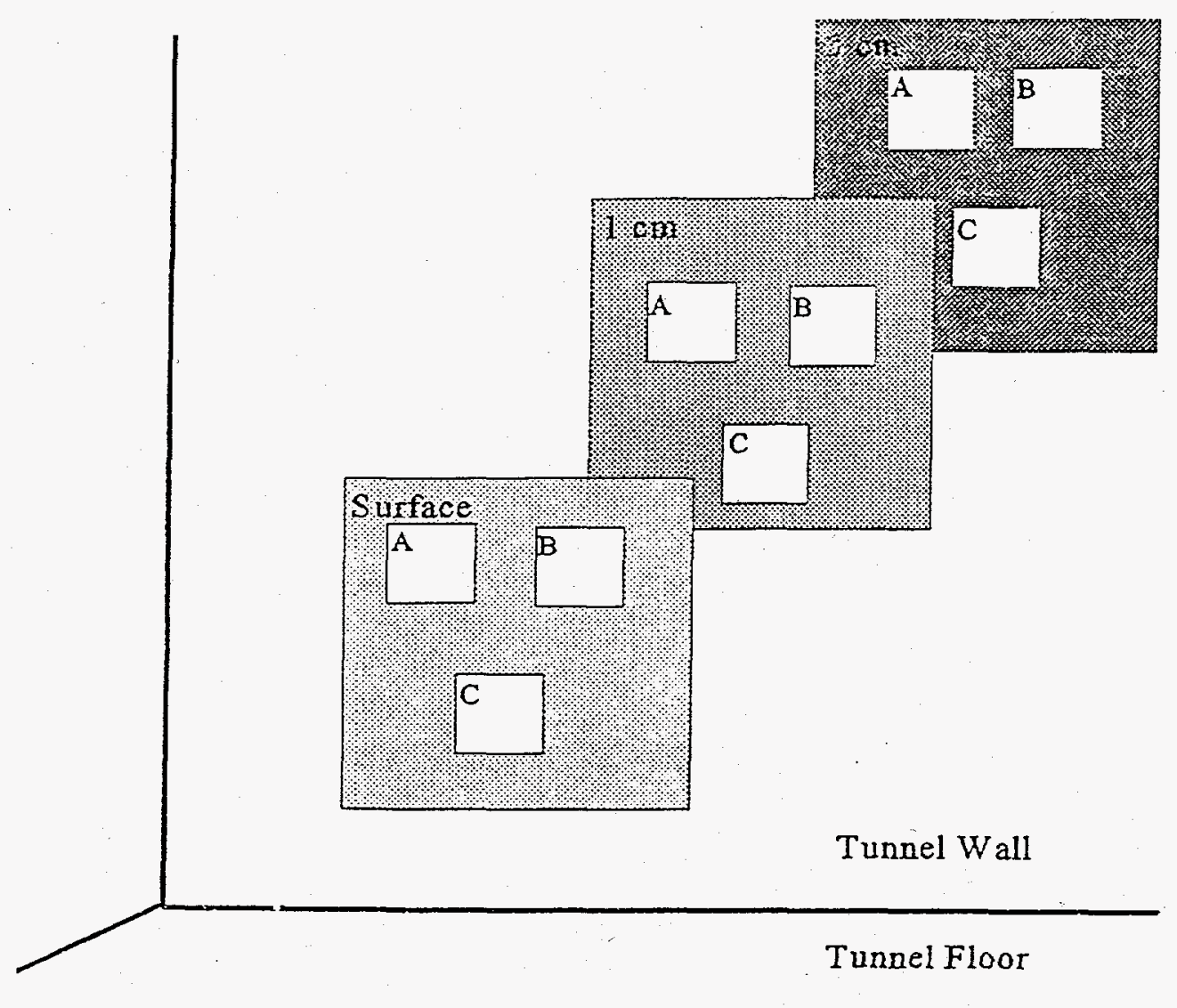

Tunnel Wall

Tunnel Floor 


\section{Microbeads}

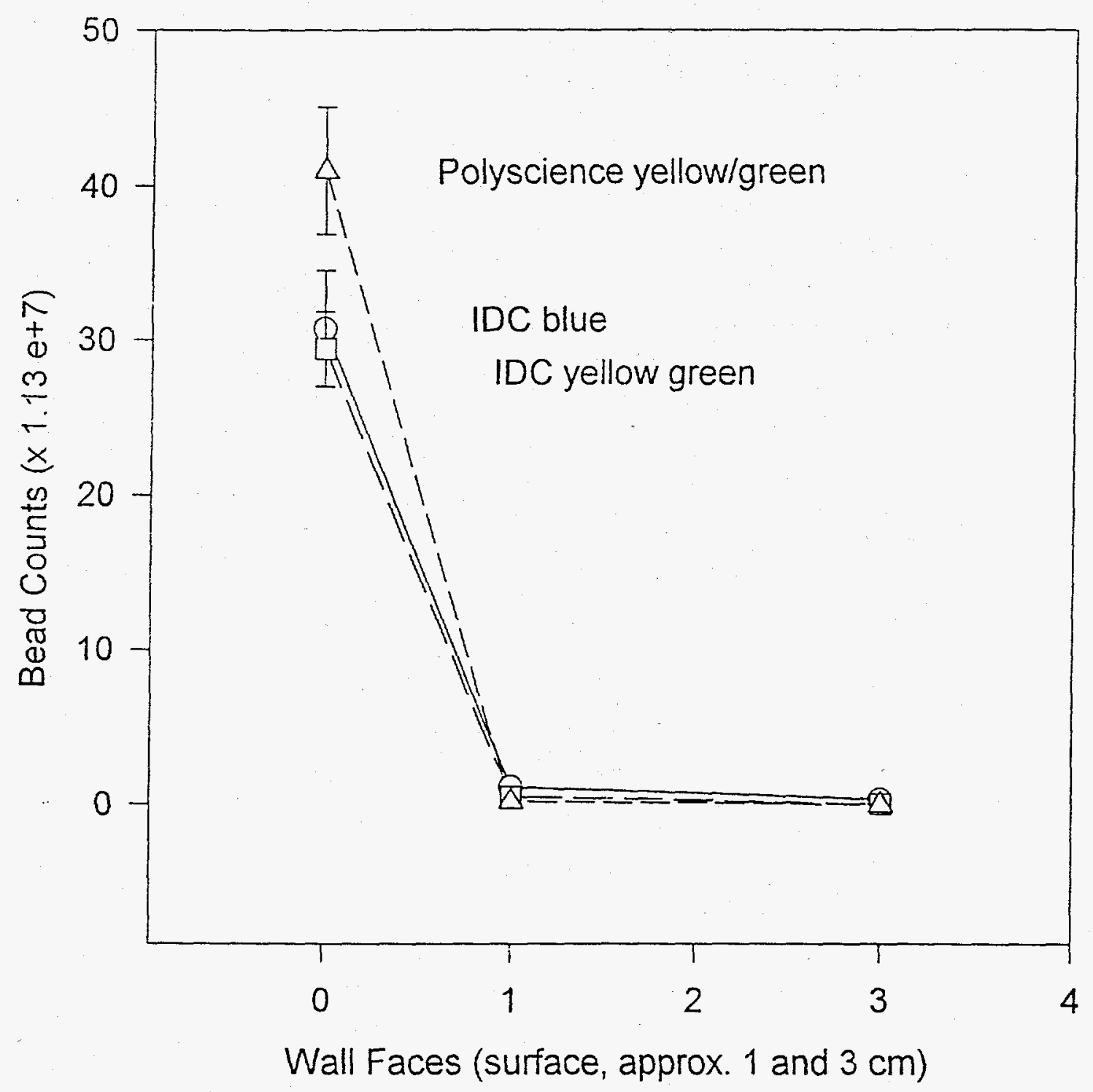




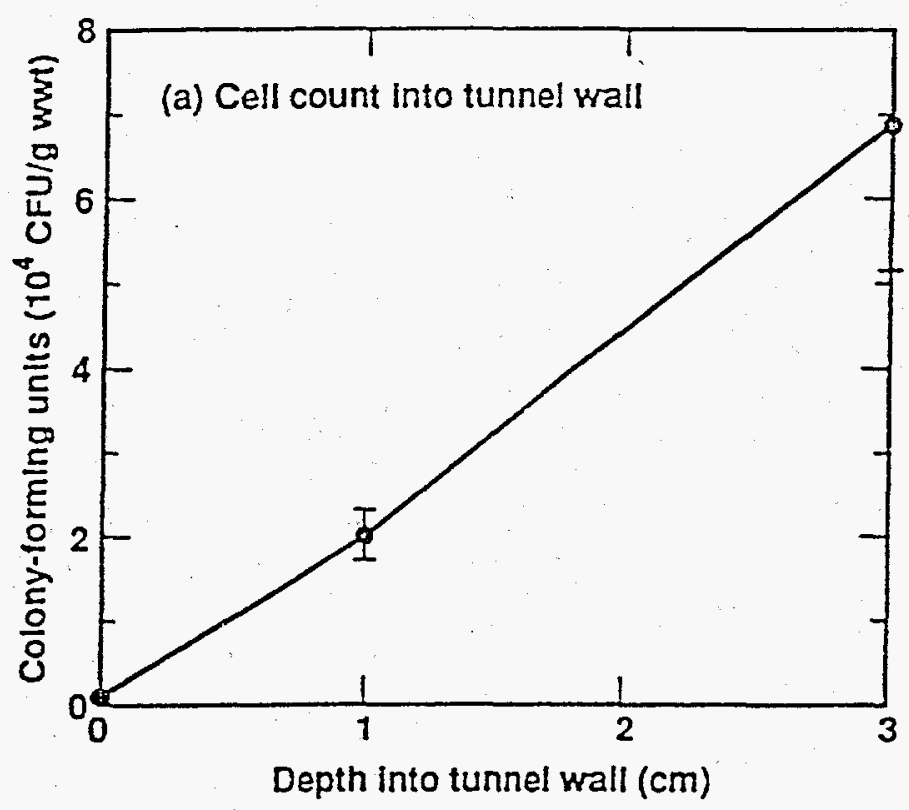




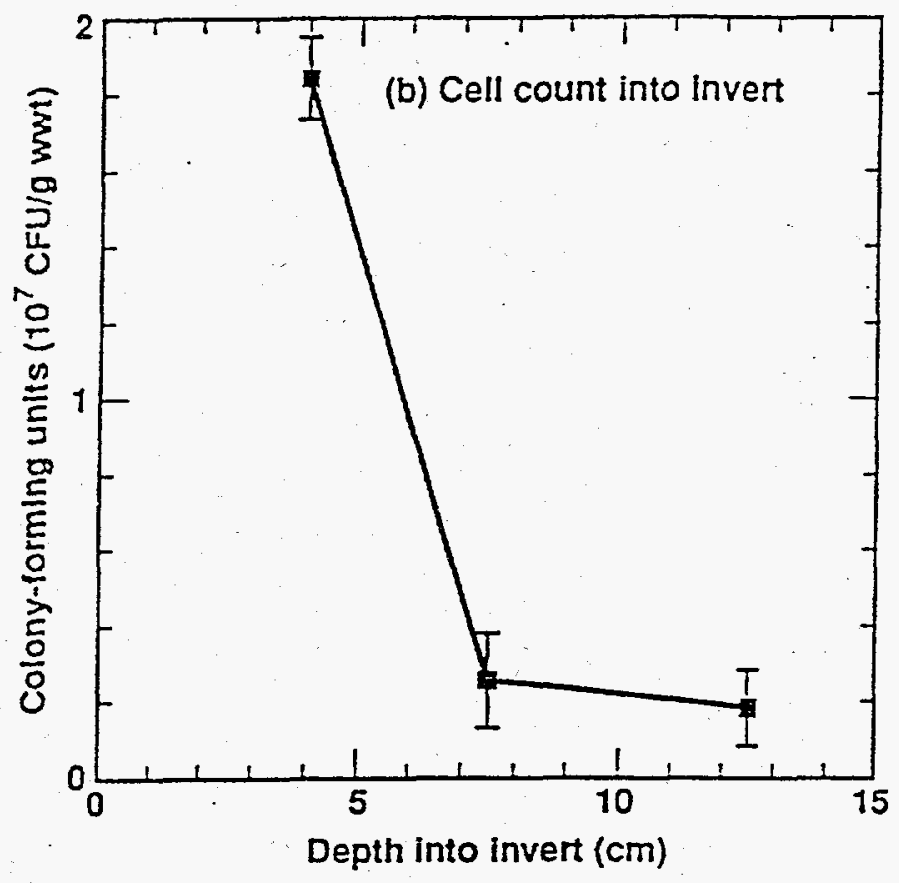




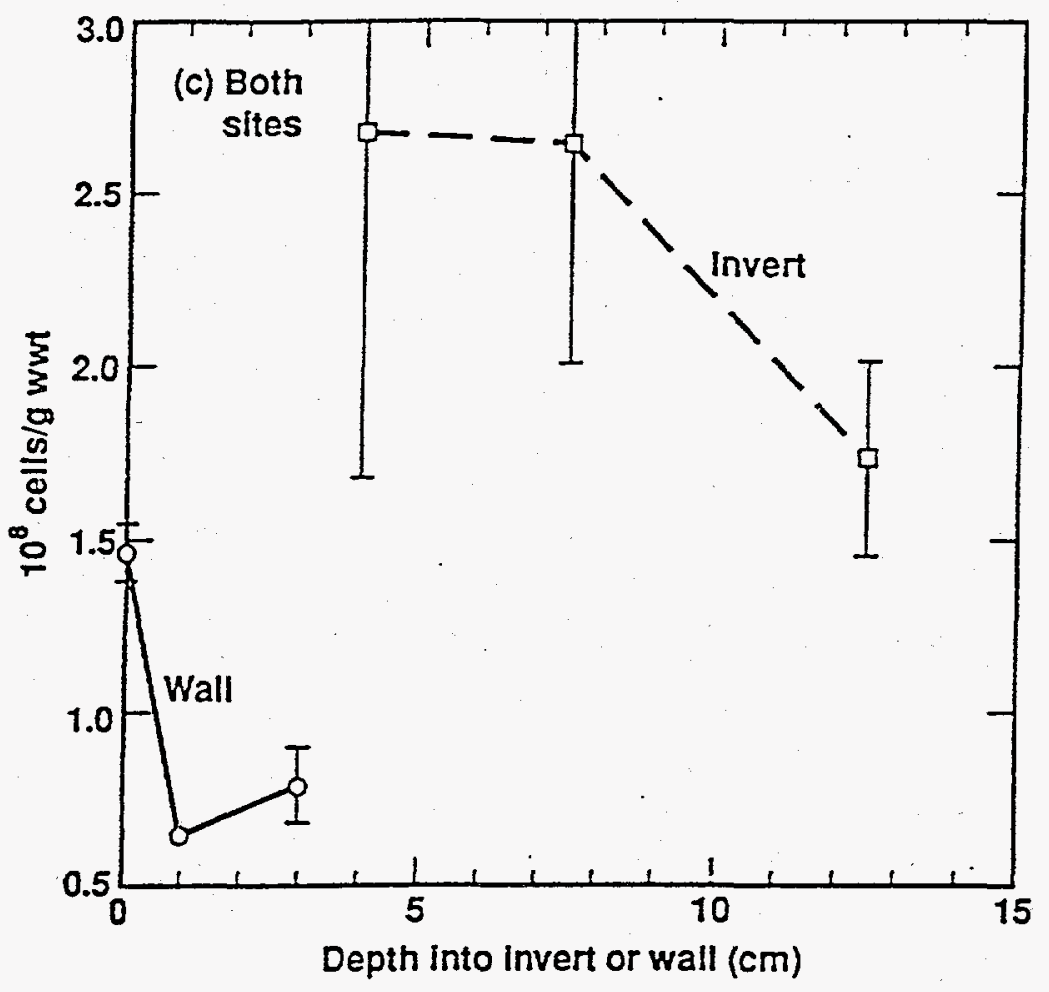




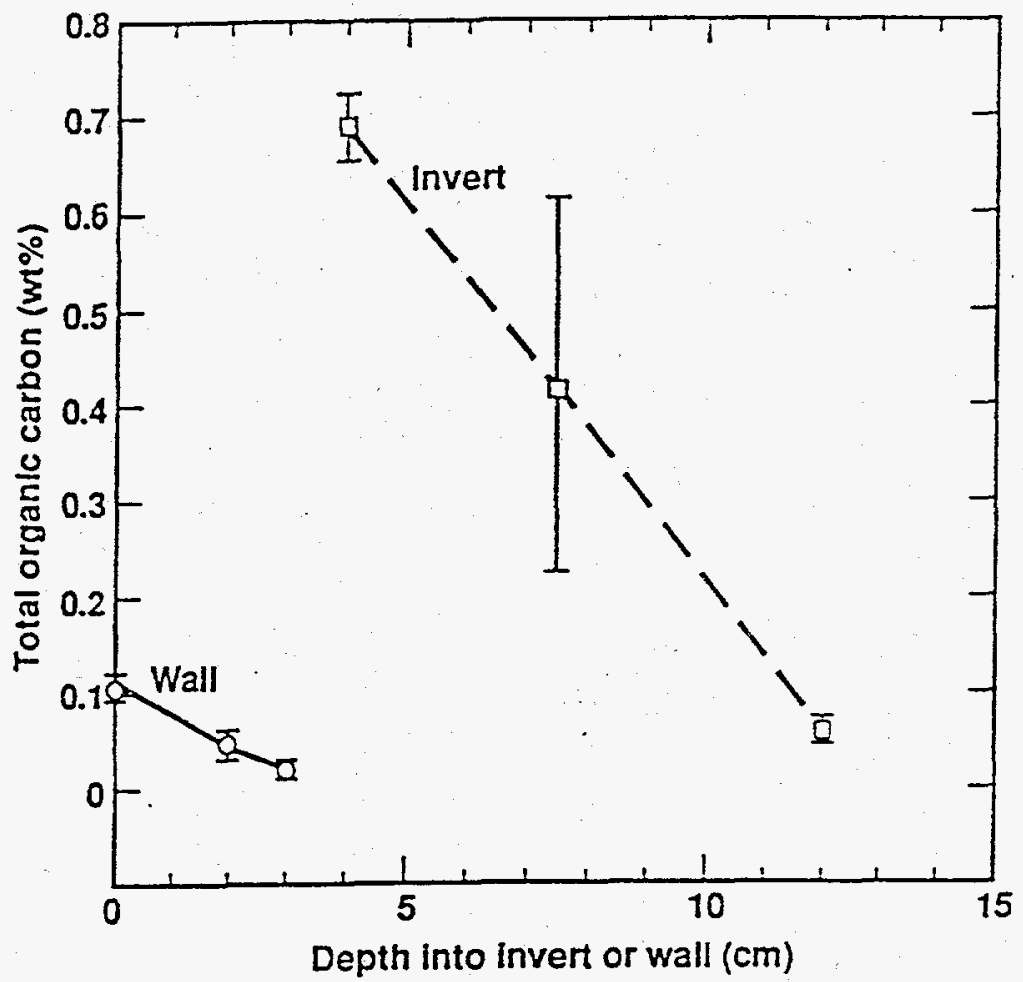




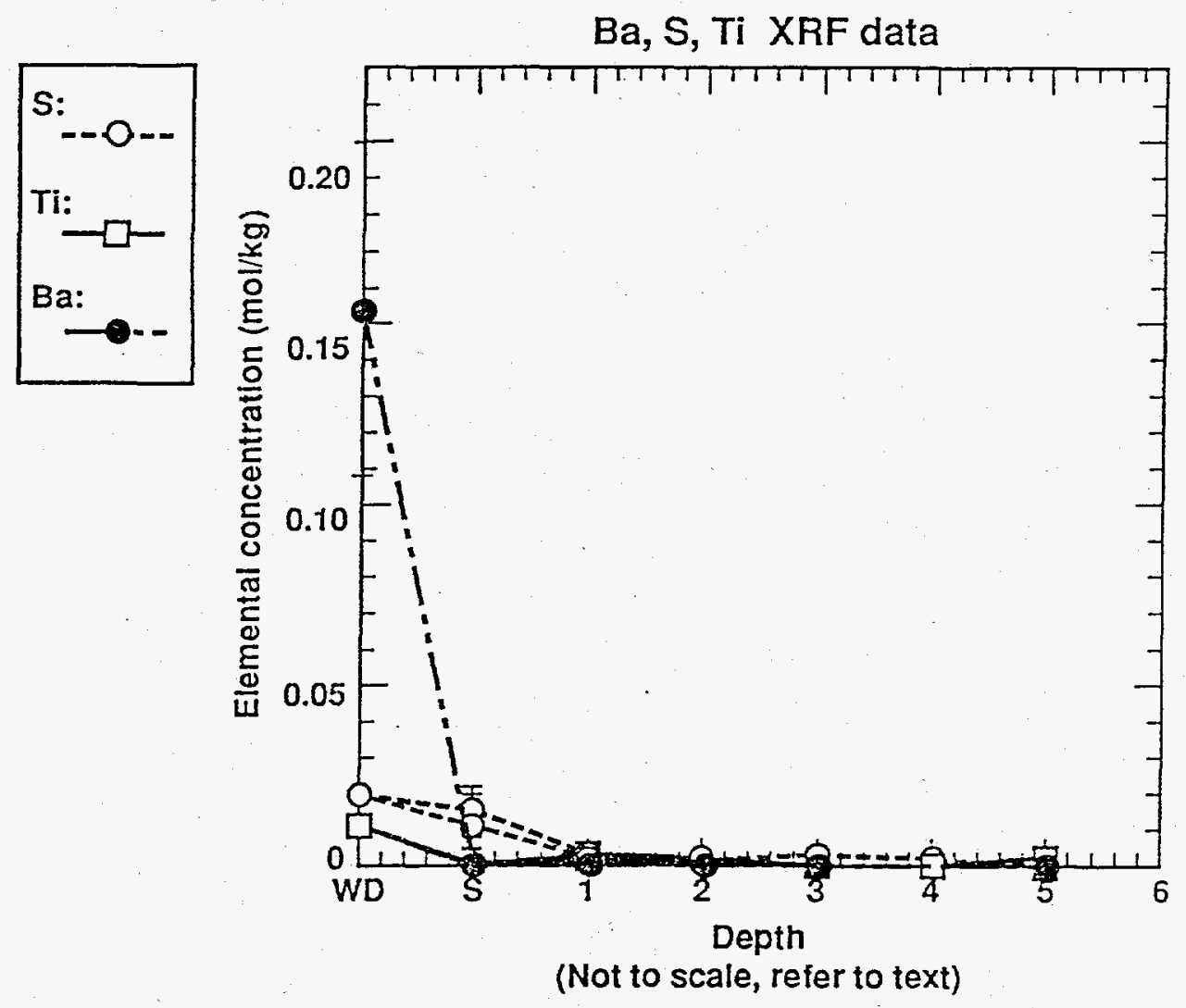

